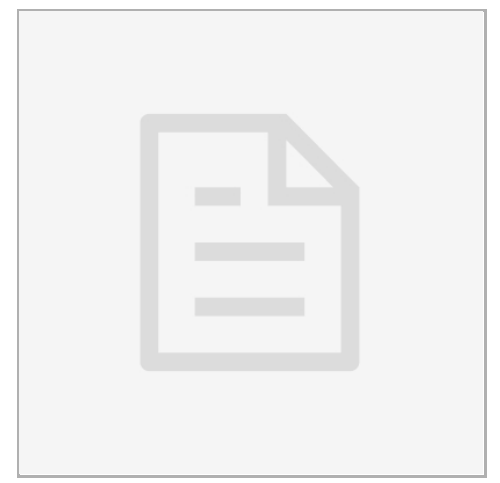

NOV 28, 2020

\section{(3) Improved methods for high yield genomic DNA of cat stools using DNeasy PowerSoil Pro Kit.}

\section{Hajar Fauzan Ahmad ${ }^{1}$}

\section{${ }^{1}$ Faculty of Industrial Sciences and Technology (FIST), Universiti Malaysia} Pahang, Malaysia.

\section{Hajar Fauzan Ahmad}

Faculty of Industrial Sciences and Technology (FIST), Univer...

\section{open ठaccess}

\section{DOI:}

dx.doi.org/10.17504/protocol s.io.bp56mq9e

\section{Protocol Citation: Hajar} Fauzan Ahmad 2020. Improved methods for high yield genomic DNA of cat stools using DNeasy PowerSoil Pro Kit.. protocols.io

https://dx.doi.org/10.17504/p rotocols.io.bp56mq9e

License: This is an open access protocol distributed under the terms of the Creative Commons Attribution License, which permits unrestricted use, distribution, and reproduction in any medium, provided the original author and source are credited

\section{Protocol status: Working} We use this protocol and it works for us for extraction of gut microbiota from cat stool samples.

Created: Nov 28, 2020

Last Modified: Nov 28, 2020

PROTOCOL integer ID: 44958

Spin the PowerBead Pro Tube briefly to ensure that the beads have settled at the bottom. Add up 
1 to $250 \mathrm{mg}$ (ideally 200 to $250 \mathrm{mg}$ ) of cat stool and $800 \mu \mathrm{l}$ of Solution CD1, together with $25 \mu \mathrm{L}$ of Proteinase K. Vortex briefly to mix.

2 Vortex at maximum speed for $10 \mathrm{~min}$. Upon completion, transfer to Eppendorf ThermoMixer to continue incubating, and mixing almost for 20 minutes at $65^{\circ} \mathrm{C}$.

3 Centrifuge the PowerBead Pro Tube at 15,000 $\mathrm{xg}$ for $1 \mathrm{~min}$. Transfer the supernatant to a clean 2 $\mathrm{ml}$ Microcentrifuge Tube (provided).

4 Add $200 \mu \mathrm{l}$ of Solution CD2 and vortex for $5 \mathrm{~s}$. Centrifuge at $15,000 \mathrm{x} \mathrm{g}$ for $1 \mathrm{~min}$. Avoiding the pellet, transfer up to $700 \mu$ l of supernatant to a clean $2 \mathrm{ml}$ Microcentrifuge Tube (provided).

$5 \quad$ Add $600 \mu$ l of Solution CD3 and vortex for $5 \mathrm{~s}$.

6 Load $650 \mu \mathrm{l}$ of lysate to an MB Spin Column. Centrifuge at 15,000 x g for $1 \mathrm{~min}$. Discard the flowthrough and repeat step 8 to ensure that all of the lysate has passed through the MB Spin Column.

7 Carefully place the MB Spin Column into a clean $2 \mathrm{ml}$ Collection Tube (provided). Avoid splashing any flow-through onto the MB Spin Column.

8 Add $500 \mu \mathrm{l}$ of Solution EA to the MB Spin Column. Centrifuge at 15,000 x g for $1 \mathrm{~min}$. Discard the flow-through and place the MB Spin Column back into the same $2 \mathrm{ml}$ Collection Tube.

9 Add $500 \mu \mathrm{l}$ of Solution C5 to the MB Spin Column. Centrifuge at 15,000 x g for $1 \mathrm{~min}$. 
10 Discard the flow-through and place the MB Spin Column into a new $2 \mathrm{ml}$ Collection Tube (provided). Centrifuge at up to $16,000 \mathrm{xg}$ for $2 \mathrm{~min}$. Carefully place the MB Spin Column into a new $1.5 \mathrm{ml}$ Elution Tube (provided).

11 Add $100 \mu$ l of Solution C6 to the center of the white filter membrane, and let the C6 remain at filter membrane for 10 minutes.

12 Centrifuge at $15,000 \times \mathrm{g}$ for $1 \mathrm{~min}$. Discard the MB Spin Column. The DNA is now ready for downstream applications.

\section{Expected result}

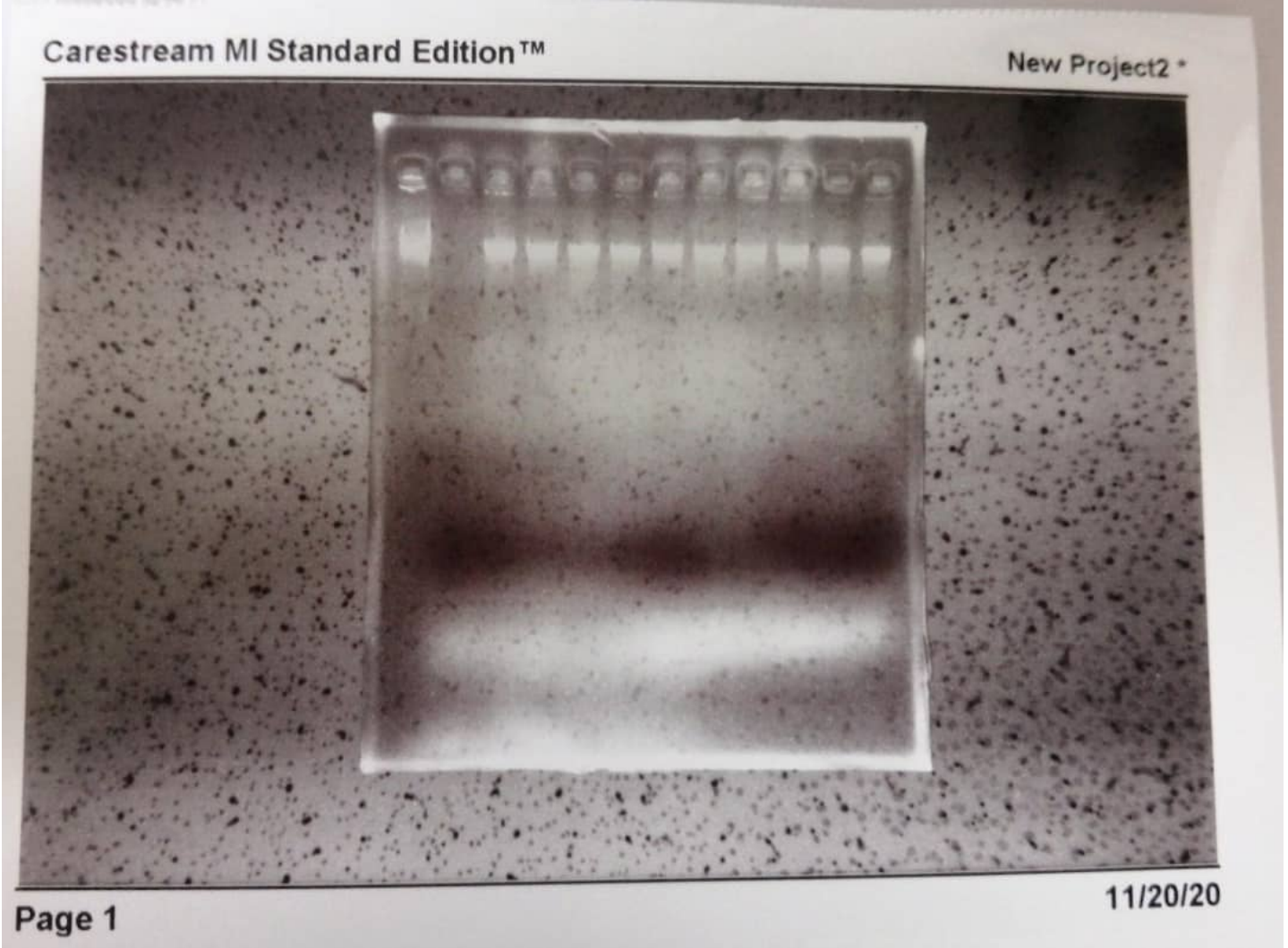

